\title{
Evaluation of Physical Education in Special Education Elementary School
}

\author{
Yusmawati \\ Faculty of Sports Science, \\ Jakarta State University, Indonesia \\ yusmawati.fikunj@gmail.com \\ Heni Widyaningsih \\ Faculty of Sports Science, \\ Jakarta State University, Indonesia \\ heniwidyaningsih@unj.ac.id
}

\author{
Taufik Rihatno \\ Faculty of Sports Science, \\ Jakarta State University, Indonesia \\ trihatno@unj.unj.ac.id \\ Sri Nuraini \\ Faculty of Sports Science, \\ Jakarta State University, Indonesia \\ srinuraini@gmail.com
}

\begin{abstract}
This research is about implementing standard learning processes for students in Special Education Elementary School. This study wanted to obtain data and information regarding the implementation of educational learning based on the standard learning process in Special Education Elementary School. Respondents in this research were the respondents that were able to provide what was needed in research such as government role in providing education services for children with special needs. The research method used an evaluative method with the design of the CIPP channel which was conducted through documentation, observation, interviews and questionnaires to the Special Education Elementary Schools in East Jakarta. Research results from the Learning Process score of 3.3 or $81 \%$; Learning Implementation scores 3,4 or $86 \%$; Assessment of Learning Outcomes has an average score of 3.4 or $84 \% \%$. Overall, the standard process of implementing education in the Special Education Elementary Schools in East Jakarta region has an average score of 3.3 or $84 \%$ which is "Very Good Category".
\end{abstract}

Keywords: learning, process standards, special education elementary schools

\section{INTRODUCTION}

The implementation of the education of children with special needs now is one of the priorities of the government so that their potential can be developed as fully as possible like other normal children. Stated in the Law on persons with disabilities in the national sports system, namely sports with disabilities, sports specifically are carried out in accordance with the conditions and physical or mental disabilities of a person (RI Law No. 3 of 2005). The children with neurodevelopmental disorders often exhibit inattention and hyperactivity/impulsivity [1]. Fundamental motion skills are necessary to be mastered by all children especially by elementary school students because these movement skills will become the foundation them to participate and be interested in the sport that they are interested in when they are grown up [2=Fadillah, 2018) .
The learning process of Physical Education is considered a very appropriate and effective media in the formation of value and character systems [3= Hariadi, 2016)]. Center class learning with the Beyond Center and Circle Time (BCCT) approach [4]. Learning assessment is carried out all the time not only when children play at the center, but starting from the reception of the child to the complete learning recorded in the assessment sheet.

Kusuma (2013) stated that there are some aspects that need to be fixed such as : (1) planning the learning media and source, (2) implementing the ICT, (3) selecting the method. Format learning models based on children's pupils are: (1) Development Themes, (2) Indicators, (3) Learning Objectives, (4) Teacher activities and Student Activities, and (5) Activity Scenario [6].

One of the activities contained in physical education is a movement consisting of locomotor, non-locomotor and manipulative which should be carried out in accordance with the standards of the implementation process as stipulated in the 2013 curriculum. This study wanted to find out whether the implementation of physical education learning process at the Special Education Elementary School in Jakarta East was in line with the standards or not.

\section{METHOD}

The research method used the evaluation research method.

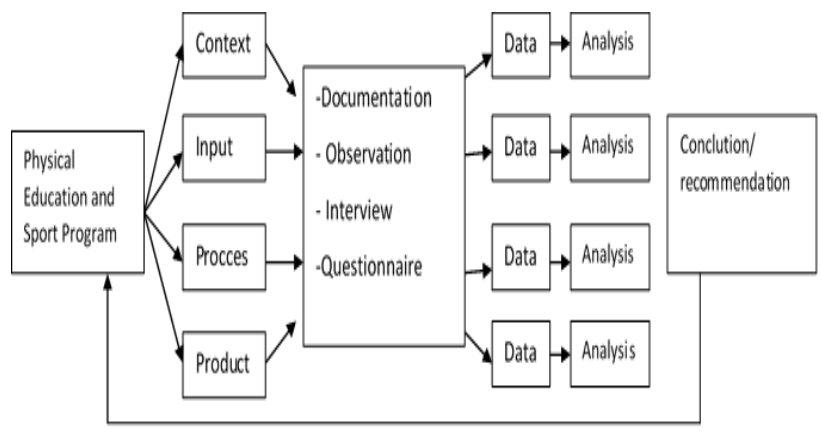

Fig. 1. Design of Research 
TABLE I. INSTRUMENT RESEARCH

\begin{tabular}{|c|c|c|c|}
\hline No & $\begin{array}{c}\text { Compo- } \\
\text { nent }\end{array}$ & Indicator & Sub indicators \\
\hline \multirow[t]{2}{*}{1.} & Context & $\begin{array}{l}\text { Special } \\
\text { Education } \\
\text { Elementary } \\
\text { School } \\
\text { physical } \\
\text { education } \\
\text { curriculum } \\
\text { a. Syllabus }\end{array}$ & $\begin{array}{l}\text { 1. ownership of the syllabus } \\
\text { 2. Syllabus components }\end{array}$ \\
\hline & & $\begin{array}{l}\text { b.Making } \\
\text { RPP }\end{array}$ & $\begin{array}{l}\text { Compilation of RPP } \\
\text { Principles for preparing RPP } \\
\text { source of books or supporting } \\
\text { documents RPP } \\
\text { RPP components } \\
\text { the purpose of making RPP }\end{array}$ \\
\hline 2 & Input & $\begin{array}{l}\text { a.learning } \\
\text { process }\end{array}$ & $\begin{array}{l}\text { open learning activities } \\
\text { Manage core activities and } \\
\text { mastery of learning materials } \\
\text { Application of the Scientific } \\
\text { Approach } \\
\text { Application of learning methods } \\
\text { Organizing sources and media / } \\
\text { learning tools } \\
\text { classroom management } \\
\text { carry out assessments } \\
\text { close the lesson }\end{array}$ \\
\hline 3. & Process & $\begin{array}{l}\text { a.Implementa } \\
\text { tion of the } \\
\text { teaching and } \\
\text { learning } \\
\text { process }\end{array}$ & $\begin{array}{l}\text { 1. Learning opening activities } \\
\text { 2. Management of core learning } \\
\text { activities } \\
\text { 3. Organizing sources and media / } \\
\text { learning tools } \\
\text { 4. The use of learning methods } \\
\text { 5. Class management } \\
\text { 6. Implementation of assessment } \\
\text { 7. Closing learning }\end{array}$ \\
\hline 4. & Product & $\begin{array}{l}\text { a. Assessment } \\
\text { of learning } \\
\text { outcomes }\end{array}$ & $\begin{array}{l}\text { 1. plan an assessment } \\
\text { 2. carry out an assessment } \\
\text { 3. processing the results of the } \\
\text { assessment } \\
\text { 4. compiling reports on learning } \\
\text { outcomes }\end{array}$ \\
\hline
\end{tabular}

\section{RESUlts AND DisCUSSION}

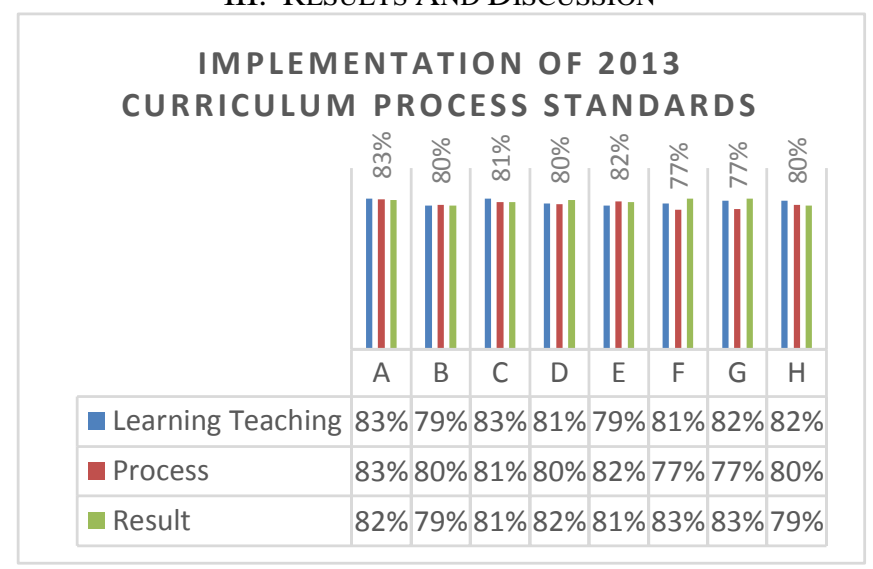

Fig. 2. Data on Standard Research Results of the Overall Special Education Elementary School Learning Process

The graph above is an overview of the results of research in the implementation of the learning process with the 2013 curriculum based on process standards. From the graph above, it can be seen that in the preparation of teaching, it obtained the lowest percentage value of $79 \%$ and the highest percentage value of $83 \%$. For the implementation of teaching, it obtained the lowest percentage value of $77 \%$, the highest $83 \%$, and the assessment of learning outcomes obtained the lowest percentage value of $79 \%$ and the highest value is $83 \%$. From the research result, an average percentage value of the implementation of the 2013 curriculum based on a standard process is $81 \%$ which is included in the excellent category.

\section{A. Results}

1) Description of Research Results and Questionnaire of Preparation of Learning Processes in the Implementation of 2013 Curriculum in Special Education School

\begin{tabular}{|c|c|c|c|c|c|c|c|}
\hline \multicolumn{8}{|c|}{$\begin{array}{c}\text { RESULTS OF FILLING OUT } \\
\text { QUESTIONNAIRE FOR LEARNING } \\
\text { PREPARATION }\end{array}$} \\
\hline \multicolumn{8}{|c|}{$\begin{array}{l}\text { E Results of Filling Out Questionnaire for Learning } \\
\text { Preparation }\end{array}$} \\
\hline $83 \%$ & $79 \%$ & $83 \%$ & $81 \%$ & $79 \%$ & $81 \%$ & $82 \%$ & $82 \%$ \\
\hline 春 & 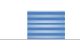 & 春 & 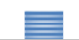 & $\underline{\underline{\underline{\underline{ }}}}$ & 春 & 春 & 鉄 \\
\hline A & B & C & D & $E$ & $\mathrm{~F}$ & $\mathrm{G}$ & $\mathrm{H}$ \\
\hline
\end{tabular}

Fig. 3. Results of Data Analysis of the First Special Education Elementary School Learning Process Preparation

From the results of the data, the average percentage of the teacher in the learning planning process for special education school A is $83 \%$ with very good category, special education school B is 79\% (very good category), special education school $\mathrm{C}$ is $83 \%$ (very good category), special education school $\mathrm{D}$ is $81 \%$ (very good category), special education school $\mathrm{E}$ is $79 \%$ (very good category), special education school $\mathrm{F}$ is $81 \%$ (very good category), special education school G is $82 \%$ (very good category), and special education school $\mathrm{H} 82 \%$ (very good category). On average, the school gets a score of $81 \%$ percentage of very good category, because it is included in the benchmark criteria that have been made that the percentage value of $75 \%-100 \%$ is categorized as "very good". This indicates that in terms of preparation, special education school teachers in East Jakarta are so ready because these schools have documents related to preparation such as syllabus, annual programs, semester programs and weekly / daily programs.

2) Description of Research Results and Questionnaire of Process of Learning Implementation in the Implementation of the 2013 Special Education School Curriculum

The data above shows the learning implementation process which obtained the percentage for special education school A which is $83 \%$ with very good category, special school B which is $80 \%$ with very good category, special education school C which is $81 \%$ with very good category, special education school $\mathrm{D}$ which is $80 \%$ with very good category, special education school E which is $82 \%$ with very good category, special education school $\mathrm{F}$ which is $77 \%$ with very good category, special education school $\mathrm{G}$ which is $77 \%$ with very good 
category, special education school $\mathrm{H}$ which is $80 \%$ with very good category. On average, the schools get a score of $80 \%$ percentage of very good category, because it is included in the benchmark criteria that have been made that the percentage value of $75 \%-100 \%$ is categorized as "very good".

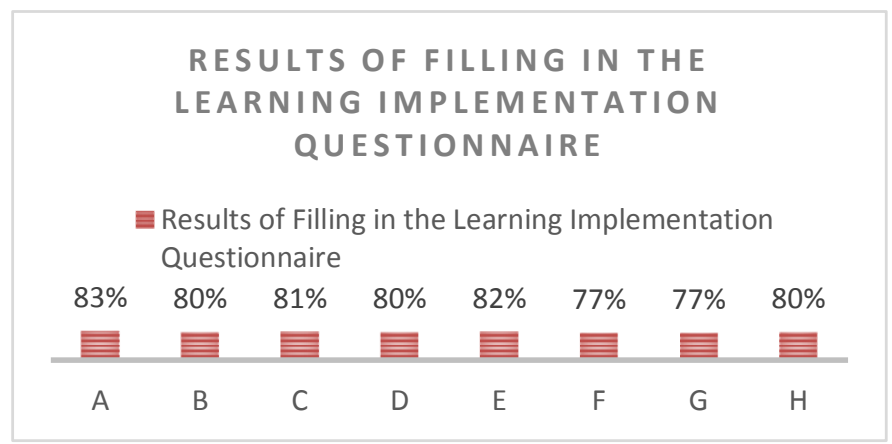

Fig. 4. Results of Data Analysis of the Second Special Education Elementary School on Learning Implementation

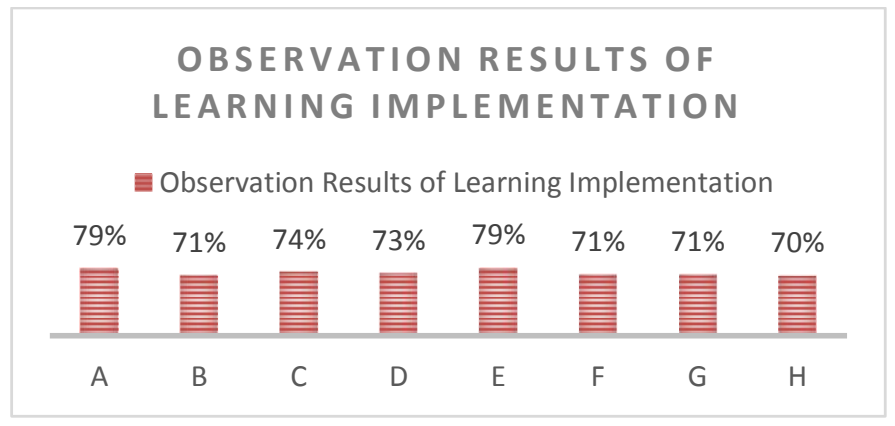

Fig. 5. Data from observations of the Third Special Education Elementary School learning process

The data above shows that the average value of the teacher in the learning process which obtained percentage for special education school A is $79 \%$ with very good category, special education school B is $71 \%$ with good category, special education school $\mathrm{C}$ is $74 \%$ with good category, special education school D is $73 \%$ with good category, special education school $\mathrm{E}$ is $79 \%$ with very category good, special education school $\mathrm{F}$ is $71 \%$ with good category, special education school $\mathrm{G}$ is $71 \%$ with good category, and special education school $\mathrm{H}$ is $70 \%$ with good category. The average schools get a score of $74 \%$ good category since it is included in the benchmark criteria that have been made that the percentage value of $50 \%$ $75 \%$ is "good category".

\section{3) Description of the learning outcomes assessment questionnaire data}

The data above shows that the average value of the teacher in the process of implementing learning obtained for special education school A is $82 \%$ with a very good category, elementary special education school B is $79 \%$ with very good category, special education school C is $81 \%$ with very good category, special education school D is $82 \%$ with very good category, special education school $\mathrm{E}$ is $81 \%$ with very good category, special education school $\mathrm{F}$ is $83 \%$ with very good category, special education school $\mathrm{G}$ is $83 \%$ with very good category, and special education school $\mathrm{H}$ is $79 \%$ with very good category. On average, the schools get a score of $82 \%$, the category is very good since it is included in the benchmark criteria that have been made that the percentage value of $75 \%$ $100 \%$, the category is categorized "very good". Some difficulties in designing and implementing learning for mentally retarded students were found. Often the teacher must get out of the written learning plan, so students move according to their wishes. Teachers are indeed required to be more flexible in learning but also must be adaptive to the characteristics of students. Besides, the main strength of the teachers is their positive perception of their students. They assume that mentally retarded students are children who have great potential in their bodies who only need more attention to bring them up.

\section{RESULTS OF FILLING IN THE LEARNING ASSESSMENT QUESTIONNAIRE}

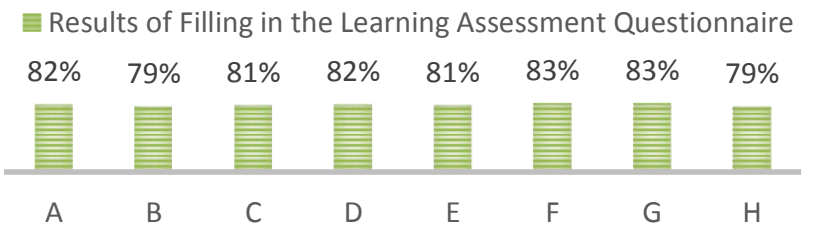

Fig. 6. Results of data analysis of the Special Education Elementary School on learning outcomes assessment process

\section{B. Discussion}

This study aims to determine the implementation of learning referring to the standard implementation process in the 2013 curriculum at the Special Education Elementary Schools in East Jakarta. There are three aspects examined in this study: planning the implementation of learning, the implementation of the learning process, and the implementation of learning outcomes assessment. Teachers in the field of sports and health physical education studies in the 2013 curriculum are required to be able to apply the material into an integrative thematic form, which is a learning model directed at character education and integrating learning content with other subjects [7]. Based on the data description described above, the discussion is as follows:

\section{1) Planning the Implementation of Learning}

The results of the analysis of the preparation of the implementation of learning by the teacher indicate that the planning is very good. This is indicated by an average value of 3.3 and a percentage value of $81 \%$ which is included in the excellent category. This shows that before learning, the teacher prepares everything very well and in detail in order to provide good learning so that learning objectives can be achieved properly.

\section{a) Syllabus}

In this 2013 curriculum, teachers no longer make syllabus because it has been given from the Secondary and Non-Formal Education Service through a school intermediary. At this time, the teacher only needs to understand the syllabus. Once 
understood, it will then be developed into the Lesson Plan (RPP). Even though they do not arrange anymore, all they have to do is understanding the syllabus. According to the interview results, there were still some obstacles encountered by the teacher. By changing the curriculum, resulting in teachers to must understand the new syllabus and redesign learning to be implemented. According to the 2013 curriculum rules, there are some additional learning materials that are not previously available in the Education Unit Level Curriculum, so teachers must look for material descriptions and also supporting material as teaching materials during learning.

\section{b) Lesson plan}

After the teacher understands the syllabus, it continues with the preparation of the lesson plan. There are several indicators in making the lesson plan. Following is a discussion of each indicator from making the lesson plan.

The results of the analysis of the preparation of RPP obtained is in very good category. This shows that the teacher has compiled the lesson plan before teaching properly. This year the teacher prepared a new lesson plan in accordance with the 2013 curriculum. There are teachers making their own lesson plans with reference to Permendikbud No 81a.

The results of the analysis of the principles of the preparation of RPP obtained is in very good category. This shows that in the preparation of the lesson plan, teachers pay attention to each of the principles for the preparation of the lesson plan in accordance with Permendikbud No. 81a in 2013. The teacher sets out the lesson plan from the syllabus to direct student learning activities with the goal that students can achieve basic competencies. The teacher designs lesson plans so that learning is centered on students. The sources are from books or supporting documents. The supporting documents of the lesson plan are documents that are used as a reference in the preparation of the lesson plan. The document is based on Permendikbud No. 81a regarding the Implementation of the Curriculum.

The results of the analysis of the lesson plan components are very good. This shows that in the preparation of the lesson plan, teachers pay attention to the components of the lesson plan. These components include:

- School identity,

- Core competencies,

- Basic competencies and indicators,

- Learning objectives,

- Learning Materials,

- Learning Methodology: Scientific Approach method, Problem Based Learning, Project Based Learning, Learning of discovery

- Learning Resources,

- Steps in learning activities,

- Assessment.

The results of the analysis of the purpose of making lesson plans are in very good category. This shows that in the preparation of the lesson plan, teachers pay attention to the purpose of the lesson plan. The several objectives of the compilation of RPP include (1) The lesson plan is made so that students are able to master competencies in the aspects of affective (attitude), cognitive (knowledge), and psychomotor (skills), (2) lesson plan is arranged so that students can provide feedback and follow-up in learning to be carried out.

With the change in curriculum which was previously the Education Unit Level Curriculum and changed to the 2013 Curriculum, there are several different things in the planning of learning implementation. From the start of compiling the syllabus, now all that remains is to understand the syllabus because it already exists from the center; teachers must prepare lesson plans in a format that is different from the previous curriculum; the existence of new subject matter so that teachers are required to be able to master and understand the subject matter. Even so, teachers in special education schools throughout East Jakarta can still carry out learning planning well.

\section{2) Implementation of the Learning Process}

Demonstrating the implementation of the learning process is included in very good category that can be seen from the value obtained which is an average value of 3.2 with a percentage of $80 \%$. This shows that the implementation of the learning process according to the teacher and the results of observations have been going very well and in accordance with the learning objectives. The implementation of the learning process includes opening learning activities, managing core activities and mastery of learning materials, applying a Scientific Approach, using resources and media / learning tools, managing classrooms, carrying out assessments, and closing the learning activity. Some of these activities are conducted so that learning process can make students master the competencies expected in accordance with the lesson plan. Following is the discussion of the analysis in the implementation of the learning process.

\section{a) Opening activities}

Before starting learning, the teacher checks student attendance. All teachers check the attendance of students just before the learning process is carried out. Psychological and physical preparation of students to follow the learning process is also very important to do to support smoothness, order, and create an atmosphere of learning can begin. Therefore, students can be interested in participating in learning and also students can concentrate on the lesson. Teachers always carry out physical and psychological preparation of students before the learning process.

\section{b) Managing core activities and material mastery}

The results of data analysis on the management of core activities and mastery of learning materials are included in the excellent category. This shows that the teacher manages the core activities and mastery of learning materials well, although there are still some shortcomings.

\section{c) Organizing resources and learning media / tools}

The results of data analysis of organizing resources and media/ learning tools are included in the excellent category. The results of data analysis organizing sources and media/ learning tools according to students are included in the excellent category. While the results of data analysis organizing sources and media / learning tools according to the results of 
observations are included in both categories. This shows that the teacher has used learning resources, learning media and learning tools to make learning effective, although there are some things that need to be improved.

\section{d) Application of learning methods}

The results of data analysis of the application of learning methods are included in the excellent category. The results of the data analysis of the application of learning methods according to students are included in the excellent category while the results of the data analysis of the application of learning methods according to the results of observation included in both categories. This shows that in the use of learning methods, teachers have approached the rules in Permendikbud No. 81 of 2013. In these rules, it is stated that in the implementation of learning with the 2013 curriculum, it uses 4 learning methods, namely the Scientific Approach method, the Problem Based Learning method, the Project Based method Learning, and the Learning Learning method. Yet, in observing the learning process and interviews conducted with the teacher, there are some things that are lacking.

\section{e) Class management}

The results of class management data analysis are included in the excellent category. The results of class management data analysis according to students are included in the excellent category while the results of class management data analysis according to the observations included in the category is very good. This shows that in the implementation of learning, teachers do class management well. Class management aims to make the learning atmosphere comfortable, conducive and fun.

\section{f) Carrying out an assessment}

The results of the data analysis of the assessment carried out by the teacher showed that the category is very good. The results of the data analysis of the implementation of the assessment according to students is included in the excellent category while the analysis of the implementation of the assessment according to the results of observations included in the excellent category. This shows that in the learning process, teachers also carry out assessments well because assessment is conducted not only at the end of learning or during daily tests and examinations.

\section{g) Closing activity}

The results of the data analysis on closing the lessons according to the teacher are included in the excellent category. The results of the data analysis covered learning according to students are included in either category while the results of data analysis close learning according to the results of observations are included in the excellent category. This shows that the teachers review and reflect the lesson well. The closing activity of learning aims to make learning that has been achieved can be accommodated properly by students.

\section{3) Implementation of assessment of learning outcomes}

The results of the analysis of the implementation of the learning outcomes assessment conducted by the teacher showed that the category is very good. This is indicated by an average value of 3.3 with a percentage of $82 \%$ which is included in the excellent category. This shows that the implementation of assessment of learning outcomes is in accordance with Permendikbud No. 81a on the Implementation of Curriculum.
The implementation of assessment of learning outcomes includes assessment of attitudes (affective), cognitive (knowledge), and psychomotor (skills).

\section{a) Planning an assessment}

The results of the assessment planning data analysis fall into the excellent category. This shows that the teacher plann the assessment well in order to get the true value of students' competence. In planning an assessment, aspects must be determined in advance. The aspects assessed include the assessment of knowledge competencies, skills competencies and also attitude competencies. To carry out the assessment, the teachers plan the assessment with various assessment instruments including essay questions, check points, practical skills tests, attitude observations, etc. In addition to determining the assessment instruments, determining the assessment questions must also be done. Before compiling the questions used for the test, the teachers also compile a grid of learning evaluation questions. Assignments prepared by the teacher also vary, including questions, discussion, observation, etc.

\section{b) Implementation of assessment}

The results of the data analysis of the implementation of the assessment carried out by teachers are included in the category "very good". This shows that the assessment conducted by the teacher is in accordance with the rules and principles of assessment in Permendikbud No. 81a 2013 concerning the Implementation of the Curriculum.

\section{c) Processing results of assessment}

The results of analyzing the data on processing of research results are included in the excellent category. This shows that each teacher processes the results of the assessment. Processing the results of this assessment aims to get the final grade. The final grade is derived from a combination of assignments, daily test scores and test scores with their respective weights. Special Education Elementary Schools throughout East Jakarta have implemented the 2013 Curriculum so that students' learning completeness competences in knowledge and skills

\section{CONCLUSION}

Based on the results of the discussion about the standard processes in the implementation of 2013 of physical education learning curriculum in special education schools throughout East Jakarta, the following conclusion is the implementation of special education school on Physical Education learning based on process standard in the 2013 curriculum is $81 \%$ and is included in the excellent category.

\section{REFERENCES}

[1] V. Tsimaras, M. Papaiouannou, M. Proios, E. Potiadou, D. K. Karidas, and M. Kotzamanidou, "The Effect Of a Digital Interactive Game In Distractibility, Hyperactivity and Impulsivity In Individuals With Attention Deficit Hyperactivity Disorder and Intellectual Disability," in Journal of Physical Education and Sport, vol.14. no. 4, 2014, pp. 500-506.

[2] A. Fadillah, S. Syamsuramel, M. Ahmad, and D. Destriana, "Latihan Medicine Ball Terhadap Hasil Chest Pass Pada Permainan Bola Basket Siswa Putra SMP," in Altius: Jurnal Ilmu Olahraga dan Kesehatan,vol 7 no. $2,2018$.

[3] B. Hariadi, M. J. D. Sunarto, and P. Sudarmaningtyas, "Development of web-based learning application for generation $z$," in International Journal of Evaluation and Research in Education, vol. 5 no. 1, 2016, pp. 60-68. 
[4] R. Ridho, M. Markhamah, dan D. Darsinah, "Pengelolaan Pembelajaran Pendidikan Anak Usia Dini (PAUD) di KB "Cerdas" Kecamatan Sukorejo Kabupaten Kendal," in Jurnal Penelitian Humaniora, vol. 16, no. 2, 2015, pp. 59-69.

[5] A. I. Kusuma and S. Irawati, "Pengembangan media pembelajaran melalui permainan hunting treasure pada materi himpunan untuk siswa kelas bilingual VII-A di SMP Negeri 16 Malang," in Jurnal Universitas Negeri Malang, vol.1 no.2, 2013, pp. 1-6.
[6] W. S. Suherman, S. Nopembri and N. R. Muktiani," Development Of Traditional Children Play Based Instructional Model To Optimize Development Of Kindergarteners'fundamental Motor Skill" in Jurnal Pendidikan Jasmani Indonesia, vol. 11 no. 2, 2015.

[7] N. Pranawati, "Survei Keterlaksanaan Kurikulum 2013 Pada Mata Pelajaran Penjasorkes Di SMP Sasaran Kota Mojokerto," in Jurnal Pendidikan Olahraga dan Kesehatan, vol. 2 no. 3, 2014. 